\title{
Green Jobs in the Development of Labor Law in Indonesia
}

\section{Green Jobs dalam Pembangunan Hukum Ketenagakerjaan di Indonesia}

\author{
Wandi $^{1^{*}}$, Ahmad Rifa'i ${ }^{2}$ \\ ${ }^{1}$ Fakulti Hukum, \\ Universiti Islam Indragiri - Tembilahan - Riau, INDONESIA \\ ${ }^{2}$ Fakulti Ekonomi, \\ Universiti Islam Indragiri - Tembilahan - Riau, INDONESIA \\ *Corresponding Author
}

DOI: https://doi.org/10.30880/jstard.2020.02.03.001

Received 30 September 2020; Accepted 30 November 2020; Available online 31 December 2020

\begin{abstract}
All government and development policies and actions must ask permission for human rights to a good and healthy environment. There should be no more policies contained in laws or regulations under those laws that debate pro-environment constitutional provisions (green laws) or with the reinforcement of other policies that are nuanced environment or green must be in accordance with the laws and regulations. The invitation (green legislation) addresses the mandate in Article 44 of Law Number 32 Year 2009 concerning PPLH. Green work is made a bridge to make future labor laws that are truly approved, so changes to the laws and regulations in the field of employment need to be done. Therefore, decent and environmentally friendly work is linked to the Millennium Development Goals 1 (poverty commitment) and the Millennium Development Goals 7 (environmental protection) which are complementary and not in conflict with each other. Development of Manpower Law conceptualized Green Jobs, to be effective in the midst of society, the change in law must consider three provisions namely; 1). The change in law was not carried out partially, the change must be resolved, more to the doctrine, norms that are not in accordance with the times. 2. The change must also be included in the way it is applied. 3 ). It must also be adhered to the rules (rules) that are in accordance with the philosophy of life of the Indonesian people in the hope that the agreed rules can be obeyed by the community, then in those rules (rules) there must be approval and endurance for that made by the government requested.
\end{abstract}

Keywords: Green jobs, development, employment, laws 
Abstrak: Semua dasar dan tindakan pemerintah dan pembangunan mesti meminta izin hak asasi manusia ke persekitaran yang baik dan sihat. Seharusnya tidak ada lagi kebijakan yang terkandung dalam undang-undang atau peraturan di bawah undang-undang tersebut yang membahaskan peruntukan konstitusional pro-lingkungan (undang-undang hijau) atau dengan penguatan kebijakan lain yang bernuansa lingkungan atau hijau harus sesuai dengan undang-undang dan peraturan. Undangan (undang-undang hijau) membahas amanat dalam Pasal 44 Undang-Undang Nomor 32 Tahun 2009 tentang PPLH. Green Jobs dijadikan jambatan untuk membuat undangundang perburuhan di masa depan yang benar-benar disetujui, jadi perubahan terhadap undang-undang dan peraturan di bidang pekerjaan perlu dilakukan. Oleh itu, pekerjaan yang baik dan mesra alam dikaitkan dengan Matlamat Pembangunan Milenium 1 (komitmen kemiskinan) dan Matlamat Pembangunan Milenium 7 (perlindungan alam sekitar) yang saling melengkapi dan tidak saling bertentangan. Pengembangan UndangUndang Tenaga Kerja berkonsepkan Green Jobs, agar efektif di tengah masyarakat, perubahan undang-undang harus mempertimbangkan tiga ketentuan iaitu; 1). Perubahan undang-undang tidak dilakukan sebagian, perubahan harus diselesaikan, lebih kepada doktrin, norma-norma yang tidak sesuai dengan zaman. 2. Perubahan itu juga mesti dimasukkan dalam cara penerapannya. 3). Ini juga harus dipatuhi dengan peraturan (peraturan) yang sesuai dengan falsafah hidup masyarakat Indonesia dengan harapan agar peraturan yang disepakati dapat dipatuhi oleh masyarakat, maka dalam peraturan tersebut (peraturan) harus ada persetujuan dan daya tahan untuk yang dibuat oleh pemerintah diminta.

Kata Kunci: Green jobs, pembangunan, pekerjaan, undang-undang

\section{Pengenalan}

Perubahan iklim merupakan salah satu tantangan utama untuk Indonesia. Kepulauan Indonesia telah diidentifikasi sebagai salah satu daerah di Asia yang paling rentan terhadap bahaya perubahan iklim, karena Indonesia merupakan Negara tropis yang sangat bergantung pada pertanian dan sumber daya alam. Bedasarkan data Bank Dunia (2009), perubahan iklim akan berimbas pada perubahan suhu lingkungan, kenaikan curah hujan, pergesaran pola musim hujan yang lebih pendek, peningkatan resiko banjir, berkurangnya kesuburan tanah, kenaikan permukaan air laut, terjadinya kenaikan suhu di laut dan serta terjadinya penurunan tanah. ${ }^{1}$

Isu mengenai tanggung jawab negara terhadap perlindungan dan pengelolaan lingkungan hidup baru mulai disadari serta dilakukan oleh negara-negara di dunia baik negara maju dan negara berkembang pasca pembangunan dunia yang menyebabkan menurunnya kualitas lingkungan secara global. Salah satu permasalahan lingkungan global yang mendapat perhatian dan harus dihadapi oleh masyarakat dunia saat ini adalah global warming (pemanasan global) yang menyebabkan perubahan iklim. Pemanasan global merupakan permasalahan modern dan rumit. Kemiskinan, ekonomi, pembangunan dan pertumbuhan penduduk menjadi penyebabnya. Bukan hal yang mudah untuk mengatasinya dan apabila tidak mempedulikannya akan membuat keadaan menjadi semakin buruk. ${ }^{2}$

Sejak manusia mulai disadarkan akan pentingnya menjaga lingkungan hidup pada dekade 1970-an, upaya untuk melegalisasi lingkungan hidup di dalam hukum negara sudah muncul. Negara-negara di berbagai belahan dunia melakukan legalisasi lingkungan hidup ke dalam peraturan perundang-undangan dan kebijakan lainnya. Indonesia baru pada Tahun 1997 mengeluarkan Undang-Undang tentang Lingkungan Hidup Nomor 23 Tahun 1997 sebagaimana telah diubah dengan Undang-Undang Nomor 32 Tahun 2009 tentang Perlindungan dan Pengelolaan Lingkungan Hidup selanjutnya disingkat UUPPLH. Permasalahan lingkungan hidup terus berlangsung meskipun sudah banyak negara yang membuat Undang-undang tentang Lingkungan Hidup. Legalisasi lingkungan hidup dalam bentuk peraturan perundang-undangan dan kebijakan pemerintah dianggap belum cukup untuk menguatkan komitmen negara dalam mengatasi persoalan lingkungan hidup. Kegagalan ini juga terjadi karena masa jabatan pemerintah yang sangat singkat dan mudahnya dilakukan perubahan terhadap Undang-undang dan kebijakan pemerintah lainnya. Sedangkan persoalan lingkungan hidup adalah persoalan yang dampaknya terjadi dalam waktu yang panjang sehingga harus ditanggulangi dengan instrumen yang berlaku lama pula. ${ }^{3}$

Dalam rangka mengatasi dampak pemanasan global dan perubahan iklim untuk mencapai pembangunan berkelanjutan, Indonesia telah berkomitmen dalam penurunan emisi gas rumah kaca (GRK) pada Tahun 2020 sebesar $26 \%$ dari kondisi tanpa rencana aksi (business as usual-BAU) dengan usaha sendiri serta penurunan $41 \%$ dengan

${ }^{1}$ The World Bank, 2009. Country Environmental Analysis. Jakarta: The World Bank The World Bank, di Kutip dalam Tulisan Jurnal Nadya Citra Ardiani, Janti Gunawan, Yudha Prasetyawan Jurusan Teknik Industri Institut Teknologi Sepuluh Nopember (ITS) Surabaya Kampus ITS Sukolilo Surabaya 60111 Email: nadyacitraardiani@gmail.com, di akses dalam laman http://digilib.its.ac.id/public/ITS-paper-32198-2509100117-paper.pdf, pada Tanggal 12 Februari 2020 Pukul 09.51 Wib.

2Jawade Hafidz, 2011, "Ekologi Konstitusional (Green Constutional) Dan Kedaulatan Wilayah Di Indonesia", Jurnal Hukum Vol XXVI, No. 2, Agustus 2011, hlm, 537. Diakses melalui https://media.neliti.com/media/publications/12326-ID-ekologi-konstitusional-green-constutionaldan-kedaulatan-wilayah-di-indonesia.pdf, pada tanggal 12 Februari 2020, Pukul 10.22 Wib.

${ }^{3}$ www.wikipedia.com/greenconstitutions, diakses tanggal 12 Februari 2020, Pukul 10.19 Wib. 
dukungan internasional. ${ }^{4}$ Salah satu tantangan terbesar dalam membangun Indonesia menjadi lebih hijau adalah meningkatkan kualitas sumber daya manusia (SDM). Setiap manusia dituntut memiliki kompetensi individu untuk berinovasi guna memacu pembangunan berkelanjutan di segala bidang. Sehingga nantinya pekerjaan yang dilakukan menjadi lebih green atau ramah lingkungan. Hal ini erat kaitannya dengan konsep green jobs.

Green jobs menurut definisi dari ILO adalah penciptaan lapangan pekerjaan yang layak secara ekonomi dan dapat mengurangi konsumsi energi dan bahan baku (dematerialize economy), mengurangi emisi gas rumah kaca (decarbonize economy), mengurangi limbah dan polusi, melindungi dan memperbaiki kualitas lingkungan serta mampu beradaptasi dengan perubahan lingkungan (ILO, 2008). Sehingga konsep green job ini dapat menyelesaikan dua permasalahan sekaligus, yaitu masalah ekonomi dan masalah ketenagakerjaan.

Pekerjaan yang layak dan ramah lingkungan atau green jobs telah memberi peluang untuk perluasan lapangan kerja di negara-negara yang perekonomian dan masyarakatnya sudah menerapkan pembangunan berkelanjutan. Berdasarkan laporan yang disusun Program Lingkungan Hidup PBB tentang Prakarsa Green Jobs yang disusun bersama dengan Organisasi Perburuhan Internasional (ILO), semakin banyak green jobs yang dapat tercipta sebagai manfaat dari upaya menciptakan perekonomian yang rendah karbon dan lebih berkelanjutan. Perubahan dari perekonomian saat ini ke perekonomian yang lebih hijau sering mengkhawatirkan masyarakat umum karena akan mengurangi pekerjaanpekerjaan pada sektor/kegiatan yang selama ini dianggap tidak ramah lingkungan dan berkelanjutan, yang berakibat pada peningkatan harga barang akibat penerapan standar lingkungan yang lebih ketat dan penerapan teknologi yang lebih ramah lingkungan. Pendapat ini tidak seluruhnya salah karena perubahan kepada pertumbuhan dan perekomian hijau tersebut akan mengakibatkan: (i) tergantikannya/hilangnya kegiatan yang selama ini tidak ramah lingkungan; (ii) penurunan standar kualitas lingkungan akan menambah biaya produksi; (iii) penerapan teknologi baru akan membutuhkan investasi baru bagi perusahaan sehingga akan meningkatkan biaya produksi.

Pembangunan nasional, khususnya bidang ketenagakerjaan diarahkan untuk sebesar-besarnya bagi kemakmuran dan kesejahteraan masyarakat pekerja. Oleh karena itu hukum ketenagakerjaan harus dapat menjamin kepastian hukum, nilai keadilan, asas kemanfaatan, ketertiban, perlindungan dan penegakan hukum serta keberlanjutan pembangunan nasional itu sendiri. Seiring dengan pembangunan bidang ketenagakerjaan, tampak maraknya para pelaku dunia usaha berbenah diri pasca krisis ekonomi dan moneter untuk bangun dari mimpi yang buruk, serta terpaan gelombang krisis ekonomi global yang melanda asia tenggara, di mana Indonesia tidak lepas dari terpaan gelombang tersebut. Pemerintah dalam upaya mengatasi krisis ekonomi global bersama dengan masyarakat, terutama para pelaku usaha, salah satu alasan pokok untuk menstabilkan perekonomian dan menjaga keseimbangan moneter serta menghindari kebangkrutan sebagian besar perusahaan yang berdampak terhadap sebagian besar nasib para pekerja pabrikan dan berujung pada pemutusan hubungan kerja. ${ }^{5}$

Peraturan perundang-undangan yang mengatur masalah ketenagakerjaan selalu berkembang sesuai dengan perkembangan zaman. Salah satu hal yang mempengaruhinya adalah meningkatnya perdagangan dan industri yang tumbuh di dalam masyarakat. Para pekerja yang semula bekerja di sektor pertanian kemudian mulai bergeser ke sektor industri yang tumbuh secara pesat dengan berdirinya berbagai perusahaan-perusahaan yang membutuhkan tenaga kerja. Pada dasarnya hukum ketenagakerjaan mempunyai sifat melindungi dan menciptakan rasa aman, tentram, dan sejahtera dengan mewujudkan keadilan sosial bagi seluruh rakyat. Hukum ketenagakerjaan dalam memberi perlindungan harus berdasarkan pada dua aspek, Pertama, hukum dalam perspektif ideal diwujudkan dalam peraturan perundang-undangan (heterotom) dan Kedua, hukum yang bersifat otonom. Ranah hukum ini harus dapat mencerminkan produk hukum yang sesuai cita-cita keadilan dan kebenaran, berkepastian, dan mempunyai nilai manfaat serta keberlanjutan bagi para pihak dalam proses produksi. ${ }^{6}$

Keseluruhan pengembangan ekonomi hijau tersebut di atas dan termasuk pekerjaan hijau (green jobs) memerlukan kebijakan yang tepat. Dalam kaitan ini, langkah-langkah yang perlu dilakukan oleh pemerintah Indonesia adalah menyusun kerangka pengembangan dan pengelolaan green jobs itu sendiri khususnya dalam pembangunan hukum ketenagakerjaan. Atas hal inilah, tulisan ini akan mencoba membahas mengenai bagaimana peneraspan konsep Green Jobs dalam pembangunan hukum ketenagakerjaan di Indonesia, dengan mengangkat judul "Konsep Green Jobs dalam Pembangunan Hukum Ketenagkerjaan di Indonesia”.

\section{Sorotan Karya}

Pendekatan konsep teori yang digunakan dalam menganalisis Konsep Green Jobs dalam Pembangunan Ketenagakerjaan di Indonesia adalah teori pembangunan hukum dan Teori Perubahan Hukum.

\footnotetext{
${ }^{4}$ BAPPENAS, 2010. Evaluasi Satu Tahun Pelaksanaan RPJMN 2010-2014. Jakarta: Bappenas.
}

${ }^{5}$ Pemerintah selaku pembina, pengawas, dan penindakan hukum melaksanakan aturan hukum dengan hati-hati mengingat posisi pengusaha dan pekerja merupakan aset potensial bagi negara, sekaligus subyek pembangunan nasional yang berkedudukan sama dihadapan hukum. Aturan hukum sebagai pedoman tingkah laku wajib dipatuhi para pihak dan dengan penuh rasa tanggungjawab. Kepatuhan bukan merupakan paksaan, melainkan budaya taat terhadap ketentuan hukum. Bhenyamin Hoessin, Pembagian Kewenangan Antara Pusat dan Daerah, (Malang: Universitas Brawijaya Press, 2001), hlm. 4, dikutip kembali dalam tulisan Laurensius Arliman S Jurnal Selat Volume. 5 Nomor. 1, Oktober 2017. p - 2354-8649 I e - 2579-5767 Open Access at: http://ojs.umrah.ac.id/index.php/selat, hlm, 75. Diakses melalui laman file://C:/Users/USER/Downloads/215Article\%20Text-1158-1-10-20180102\%20(2).pdf, pada tanggal 12 Februari 2020, Pukul 12.18 Wib.

${ }^{6}$ Agus Dwiyanto, et-al, 2006, Reformasi Birokrasi Publik di Indonesia, Gadjah Mada University Press, Yogyakarta, hlm. 24. 
Pertama, Teori pembangunan hukum yang digagas oleh Mohctar Kusumaatmadja dipergunakan sebagai pemikiran serta rambu aplikasi dari kontruksi pandangan penulis mengenai arti penting nilai-nilai green jobs pada peraturanperaturan perundang-undangan di bidang ketenagakerjaan dalam membangun suatu bangsa, khususnya melalui pembenahan dalam proses pembentukan hukum ketenagakerjaan di Indonesia, mengingat keberadaan Indonesia sebagai salah satu Negara berkembang. Terdapat tiga hal baru yang dikembangkan oleh Mochtar Kusumaatmadja dalam dunia hukum, yaitu konsep hukum baru, hukum sebagai sarana masyarakat, dan hukum yang ada yang bersifat netral dan tidak netral. ${ }^{7}$ Defenisi serta tujuan hukum menurut Mochtar Kusumaatmadja, penulis uraikan dalam melihat teori hukum pembangunan yang digagasnya sebagai kesatuan pandangan yang tidak terpisah antara satu dan lainnya dan merupakan bentuk dari pengembangan sebuah pemikiran. Sementara itu, Shidarta memandang bahwa Mochtar Kusumaatmadja menempatkan fungsi hukum sebagai prasyarat menuju pada tujuan hukum ${ }^{8}$.

Gagasan utama Mochtar Kusumaatmadja yang digunakan oleh penulis adalah gagasan "hukum sebagai sara pembaruan masyarakat", yang kemudian dikenal dengan nama Teori Hukum Pembangunan. Teori ini mengatakan bahwa hukum merupakan sarana pembaruan masyarakat didasarkan atas anggapan bahwa adanya keteraturan atau ketertiban dalam usaha pembangunan atau pembaruan itu merupakan sesuatu yang diinginkan atau bahkan dipandang perlu. Artinya peraturan hukum berfungsi sebagai alat (pengatur) atau sarana pembangunan dalam arti penyalur arah kegiatan manusia kea rah yang dikehendaki oleh pambangunan atau pembaruan. ${ }^{9}$

Kedua, Teori perubahan hukum oleh Thomas C. Dienes dalam Ahmad Ali ${ }^{10}$ mengemukakan bahwa "Ada Pendapat yang menganggap bahwa perubahan hukum secara formal akan menyebabkan terlibatnya badan-badan yang menggerakkan perubahan itu, terutama badan legislative dan badan peradilan". Sehubungan dengan itu Satjipto Raharjo, ${ }^{11}$ berpendapat bahwa; "Peranan mereka itu apakah ia seorang hakim atau kah legislator adalah cukup penting, oleh karena keputusan-keputusan serta tindakan-tindakan yang diambil oleh badan-badan tersebut di atas pada hakikatnya merupakan hasil karya mereka juga. Bagaimana pikiran dan sikap-sikap mereka mengenai perubahan dalam masyarakat akan sangat menentukan bagaimana badan-badan tersebut mengahdapi masalah perubahan sosial. Teori perubahan hukum ini penulis gunakan dalam penulisan karya ilmiah ini adalah untuk melihat sejauhmana perubahan lingkungan mempengaruhi perubahan kondisi hukum ketenagakerjaan itu sendiri.

\section{Metodologi}

Metode Penelitian dalam penulisan karya ilmiah ini menggunakan metode Penelitian Yuridis Normatif, yaitu penelitian yang dilakukan dengan cara meneliti bahan pustaka atau data sekunder belaka. Analisis data bersifat deduktif, berdasarkan teori atau konsep yang bersifat umum guna menunjukkan hubungan antara data dengan data lainnya. Sedangkan pendekatan yang digunakan adalah sosio normatif, karena penulisan ini menggunakan data sekunder, dengan maksud untuk mendiskripsikan Konsep Green Jobs dalam Pembangunan Hukum Ketenagakerjaan di Indonesia.

\section{Perbincangan}

\section{Penerapan Konsep Hijau (Green) dalam Pembangunan Hukum di Indonesia}

Ketentuan mengenai lingkungan hidup dirumuskan dalam Pasal 28H ayat (1) dan Pasal 33 ayat (4) UUD 1945. Pasal 28H ayat (1) UUD 1945 jelas menyatakan:

"Setiap orang berhak hidup sejahtera lahir dan batin, bertempat tinggal, dan mendapatkan lingkungan hidup yang baik dan sehat serta berhak memperoleh pelayanan kesehatan."

Hak untuk memperoleh lingkungan hidup yang baik dan sehat serta pelayanan kesehatan yang baik, merupakan hak asasi manusia. Karena itu, UUD 1945 jelas sangat pro-lingkungan hidup, sehingga dapat disebut sebagai konstitusi hijau (green constitution).

Sebagai imbangan adanya hak asasi setiap orang itu berarti negara diharuskan untuk menjamin terpenuhinya hak setiap orang untuk memperoleh lingkungan hidup yang baik dan sehat yang termasuk kategori hak asasi manusia tersebut. Sebagai hak setiap orang, tentunya secara bertimbal-balik pula mewajibkan semua orang untuk menghormati hak orang lain sehubungan dengan lingkungan yang baik dan sehat itu. Oleh karena itu, di satu segi setiap orang berhak

${ }^{7}$ Lili Rasjidi dalam kata pengantar pada Romli Atmasasmita, 2012, Teori Hukum Integratif:Rekontruksi Terhadap Teori Hukum Pembangunan dan Teori Hukum Progresif. Genta Publishing, Yogyakarta, hlm, v.

${ }^{8}$ Arif Shidarta, 2012, Mochtar Kusumaatmadja dan Teori Hukum Pembangunan: Eksistensi dan Implikasi, Epistema Institute Huma, Jakarta, hlm. 16-17.

${ }^{9}$ Mochtar Kusumaatmadja, 2006, Konsep-Konsep Hukum dalam Pembangunan, Alumni, Bandung, hlm. 88.

${ }^{10}$ Ahmad Ali, 1996, Menguak Tabir Hukum, Chandra Pratama, Jakarta, hlm 37-38, sebagaimana dikutip kembali dalam buku Aries Harianto, 2016, Hukum Ketenagakerjaan Makna Kesusilaan dalam Perjanjian Kerja, Laksbang Pressindo, Yogyakarta, hlm. 236.

${ }^{11}$ Satjipto Raharjo, 1991, Ilmu Hukum, Citra Aditya Bakti, Bandung, hlm. 66 
atas lingkungan hidup yang baik dan sehat, tetapi di pihak lain setiap orang juga berkewajiban untuk menjaga dan menghormati hak orang lain untuk mendapatkan dan menikmati lingkungan hidup yang baik dan sehat itu.

Demikian pula negara, disamping dibebani kewajiban dan tanggung jawab untuk menjamin lingkungan hidup yang baik dan sehat, juga berhak menuntut setiap orang untuk menghormati hak orang lain, dan apabila perlu memaksakan setiap orang untuk tidak merusak dan mencemarkan lingkungan hidup untuk kepentingan bersama.

Dengan ketentuan Pasal 28H ayat (1) UUD 1945, berarti norma lingkungan hidup telah mengalami konstitusionalisasi menjadi materi muatan konstitusi sebagai hukum tertinggi. Dengan demikian, segala kebijakan dan tindakan pemerintahan dan pembangunan haruslah tunduk kepada ketentuan mengenai hak asasi manusia atas lingkungan hidup yang baik dan sehat. Tidak boleh ada lagi kebijakan yang tertuang dalam bentuk undang-undang ataupun peraturan di bawah undang-undang yang bertentangan dengan ketentuan konstitusional yang pro-lingkungan ini.

Perkembangan kebijakan lingkungan hidup menurut Jimly Asshiddiqie terdiri dari 2 (dua) tahap perkembangan lingkungan hidup. ${ }^{12}$ Pada tahap pertama, atas dorongan kesadaran yang semakin luas di seluruh dunia mengenai pentingnya upaya melindungi lingkungan dari ancaman pencemaran dan perusakan, kebijakan lingkungan hidup dituangkan dalam bentuk peraturan perundang-undangan secara resmi. Dengan demikian, timbul gelombang dunia, yaitu gelombang legalisasi atau legislasi kebijakan lingkungan hidup. Setelah ditetapkan begitu banyak peraturan perundang-undangan secara resmi, ternyata kebanyakan peraturan-peraturan itu tidak efektif untuk mencegah terjadinya pencemaran dan perusakan lingkungan hidup. Ketidakpuasan demikian berkembang luas di banyak negara, sehingga muncul tuntutan untuk memperkuat payung hukum kebijakan lingkungan hidup itu dalam konstitusi sebagai hukum yang tertinggi. Perkembangan terakhir inilah yang Jimly Asshiddiqie namakan sebagai gelombang kedua atau perkembangan tahap kedua dengan melakukan konstitusionalisasi kebijakan lingkungan itu ke dalam rumusan UUD 1945.

Seperti dikemukakan di atas, pada Gelombang Pertama, kebijakan lingkungan hidup diformulasikan dalam peraturan perundang-undangan negara secara resmi. Agar memiliki kedudukan yang tinggi dengan daya paksa yang mengikat untuk umum, kebijakan lingkungan dan ide pembangunan berkelanjutan dituangkan dalam undang-undang yang dibuat oleh lembaga parlemen dan pemerintah (legislative acts). Gejala demikian ini berkembang sejak Tahun 1970-an dan berpengaruh di Indonesia pada akhir tahun 1970-an. Karena itu, pada era 1980-an, berkembang tuntutan yang meluas agar kebijaka- kebijakan resmi pemerintah Indonesia yang pro-lingkungan dapat tercermin dalam bentuk perundang-undangan yang mengikat untuk ditaati oleh semua pemangku kepentingan (stakeholders). ${ }^{13}$

Dalam ketentuan Pasal 33 ayat (4) UUD 1945 yang menyatakan:

"Perekonomian nasional diselenggarakan berdasarkan atas demokrasi ekonomi dengan prinsip kebersamaan, efisiensiberkeadilan, berkelanjutan, berwawasan lingkungan, kemandirian, serta dengan menjaga keseimbangan kemajuan dan kesatuan ekonomi nasional."

Terdapat dua konsep yang berkaitan dengan ide tentang ekosistem, yaitu bahwa perekonomian nasional berdasarkan atas demokrasi ekonomi dimaksud haruslah mengandung prinsip berkelanjutan dan berwawasan lingkungan. Dengan sendirinya menurut Jimly Asshiddiqie keseluruhan ekosistem seperti yang dimaksud dalam Pasal 33 ayat (3) UUD 1945 sebagaimana ditafsirkan secara ekstensif dan kreatif oleh pelbagai undang-undang di bidang lingkungan hidup, haruslah dikelola untuk kepentingan pembangunan berdasarkan prinsip pembangunan berkelanjutan (sustainable development) dan wawasan lingkungan (pro-environment) sebagaimana ditentukan oleh Pasal 33 ayat (4) UUD 1945. Oleh karena itu, cukup alasan untuk menyebut bahwa UUD 1945 pascareformasi atau sesudah Perubahan Keempat pada 10 Agustus 2002 juga sudah berwarna hijau atau green constitution. ${ }^{14}$

Di tengah semakin berkembangnya iklim demokrasi di berbagai negara, termasuk di Indonesia, isu keadilan lingkungan menurut Sonny Keraf telah menjelma dari sebuah gagasan yang terkesan abstrak menuju sesuatu yang memang harus dan dapat diperjuangkan bahkan seringkali keadilan memang harus direbut. ${ }^{15}$ Berdasarkan uraian di atas maka dengan ketentuan Pasal 28H ayat (1) dan Pasal 33 ayat (1) UUD 1945, berarti norma lingkungan hidup telah mengalami konstitusionalisasi menjadi materi muatan konstitusi sebagai hukum tertinggi (green constitution).

Dengan demikian, segala kebijakan dan tindakan pemerintahan dan pembangunan haruslah tunduk kepada ketentuan mengenai hak asasi manusia atas lingkungan hidup yang baik dan sehat. Tidak boleh ada lagi kebijakan yang tertuang dalam bentuk undang-undang ataupun peraturan di bawah undangundang yang bertentangan dengan ketentuan konstitusional yang pro-lingkungan ini (green legislation) atau dengan perkataan lain kebijakan yang bernuansa lingkungan hidup atau hijau harus tercermin dalam setiap peraturan perundang-undangan (green legislation) sebagaimana diamanatkan dalam Pasal 44 UU Nomor 32 Tahun 2009 yang berbunyi:

${ }^{12}$ Jimly Asshiddiqie, 2009, Green Constitution: Nuasa Hijau Undang-Undang Dasar Negara Republik Indonesia Tahun 1945, PT. RajaGrafindo Persada, Jakarta, hlm. 159.

${ }^{13}$ Ibid

${ }^{14}$ Ibid, hlm. 182.

${ }^{15}$ Sonny Keraf, 2010, Etika Lingkungan Hidup, Buku Kompas, Jakarta. 
"Setiap penyusunan peraturan perundang-undangan pada tingkat nasional dan daerah wajib memerhatikan perlindungan fungsi lingkungan hidup dan prinsip perlindungan dan pengelolaan lingkungan hidup sesuai dengan ketentuan yang diatur dalam UndangUndang ini."

Peraturan perundang-undangan berbasis lingkungan hidup (green legislation) tentu saja diperkuat dengan norma lingkungan hidup yang terkonstitusionalisasikan dalam UUD 1945 (green constitution) sebagaimana diamanatkan dalam Pasal 28H dan Pasal 33 ayat (4) UUD 1945.

Berdasarkan pada ketiga pasal tersebut, Indonesia sebenarnya telah menerapkan konsep ecocracy yaitu kedaulatan lingkungan hidup atau ekosistem di mana suatu pemerintahan mendasarkan kepemerintahannya secara taat asas pada prinsip-prinsip pembangunan berkelanjutan yang berwawasan lingkungan (ecologically sustainable development).

Gagasan ecocracy ini merupakan upaya untuk mengutamakan pembangunan berkelanjutan yang berwawasan lingkungan hidup dalam arus politik pembangunan nasional. Namun, walaupun Indonesia dalam konstitusinya telah mengakui subjective right atau duty of the state tetapi pemuatan pola dan arah pembangunan berkelanjutan belum ditempatkan pada pasal-pasal khusus melainkan ditumpangkan atau dicampurkan dengan hak-hak fundamental lainnya. Oleh karena itu, dengan teori hierarki peraturan perundang-undangan sesuai dengan Undang-Undang Nomor 12 Tahun 2011 tentang Pembentukan Peraturan Perundang-undangan, Pemerintah Indonesia wajib menyesuaikan seluruh peraturan perundang-undangan di Indonesia agar menjadi peraturan yang berkelanjutan dan berwawasan lingkungan.

\section{Konsep Green Jobs dalam Pembangunan yang Berkelanjutan (Sustainable Development)}

Banyak negara di kawasan Asia dan Pasifik secara sukarela berkomitmen mengurangi emisi gas rumah kaca pada Tahun 2020 atau intensitas karbon per unit Produk Domestik Bruto (PDB). Dalam kaitan ini, pelibatan perekonomian Asia ke dalam jejak pembangunan berkelanjutan lingkungan dan berkarbon rendah akan membawa penyesuaian yang mendasar dan berkesinambungan terhadap struktur perekonomian sosial negara-negara di wilayah tersebut. Transformasi menuju pembangunan berkelanjutan dan rendah karbon akan memicu pergeseran dalam pasar tenaga kerja dan menciptakan permintaan untuk program ketrampilan baru dan pemberian ketrampilan ulang, dan skema perlindungan sosial dan keuangan khususnya bagi pekerja dan usaha yang paling terpapar.

Dampak dari perubahan iklim dan kebijakan yang dihasilkan bagi dunia pekerjaan tidak selalu dipahami sepenuhnya, dan dalam beberapa kasus dipandang sebagai pengeluaran pada segi perekonomian dan daya kompetisi. Sementara faktanya, studi terakhir menunjukkan bahwa kebijakan-kebijakan cerdik iklim dapat membawa manfaat lingkungan, ekonomi dan sosial secara bersamaan. Perubahan pola produksi dan konsumsi yang diserukan untuk mengarah pada perekonomian ramah iklim membutuhkan perpaduan dimensi sosial, gender dan ketenagakerjaan dalam pembuatan keputusan.

Keterlibatan pihak berwenang di bidang tenaga kerja dan mitra sosial (konstituen ILO) dalam penyusunan kebijakan iklim yang inklusif dan saing berkesinambungan sangatlah dibutuhkan. Tetapi juga dibutuhkan komitmen pada tingkat politik paling tinggi untuk menjamin perdebatan kebijakan lingkungan dapat sekaligus mengatasi dimensi gender dan sosial dengan lebih menonjol dan kebijakan pemulihan pekerjaan dapat mengambil jejak yang lebih berkelanjutan lingkungan

Pekerjaan yang layak dan ramah lingkungan atau green jobs telah memberi peluang untuk perluasan lapangan kerja di negara-negara yang perekonomian dan masyarakatnya sudah menerapkan pembangunan berkelanjutan. Berdasarkan laporan yang disusun Program Lingkungan Hidup PBB tentang Prakarsa Green Jobs yang disusun bersama dengan Organisasi Perburuhan Internasional (ILO), semakin banyak green jobs yang dapat tercipta sebagai manfaat dari upaya menciptakan perekonomian yang rendah karbon dan lebih berkelanjutan.

Perubahan dari perekonomian saat ini ke perekonomian yang lebih hijau sering mengkhawatirkan masyarakat umum karena akan mengurangi pekerjaan-pekerjaan pada sektor/kegiatan yang selama ini dianggap tidak ramah lingkungan dan berkelanjutan, yang berakibat padapeningkatan harga barang akibat penerapan standar lingkungan yang lebih ketat dan penerapan teknologi yang lebih ramah lingkungan. Pendapat ini tidak seluruhnya salah karena perubahan kepada pertumbuhan dan perekomian hijau tersebut akan mengakibatkan:

(i) tergantikannya/hilangnya kegiatan yang selama ini tidak ramah lingkungan;

(ii) penurunan standar kualitas lingkungan akan menambah biaya produksi;

(iii) penerapan teknologi baru akan membutuhkan investasi baru bagi perusahaan sehingga akan meningkatkan biaya produksi.

Namun pendapat ini tidak seluruhnya benar karena:

(i) biaya produksi dan harga yang selama ini diterapkan "bukan merupakan biaya dan harga yang benar" karena selama ini biaya dampak terhadap lingkungan tidak diperhitungkan dalam biaya produksi, namun dibebankan kepada masyarakat (pihak lain);

(ii) penerapan ekonomi hijau belum tentu menghilangkan suatu industri seluruhnya, kemungkinan hanya mengganti cara kerja atau beberapa jenis pekerjaan/pekerja tertentu; 
(iii) terdapat peluang timbulnya pekerjaan baru dalam industri yang sama atau peluang produk baru yang dapat dikembangkan.

Dengan demikian, secara konseptual, pekerjaan hijau/green jobs dapat dipengaruhi oleh empat (4) hal berikut ${ }^{16}$ :

Pekerjaan baru akan tercipta/dapat diciptakan - seperti di bidang pembuatan alat pengontrol polusi yang akan dipasang pada peralatan produksi yang sudah ada. Beberapa contoh yang dapat diberikan adalah: (i) pekerjaan yang dapat membantu melindungi ekosistem termasuk di dalamnya keragaman jenis dan keragaman genetika; (ii) pekerjaan yang berkaitan dengan peningkatan efisiensi/penghematan energi, penghematan materi/bahan, dan konsumsi air yang efisien tinggi; (iii) pekerjaan terkait dengan upaya penurunan emisi karbon dalam ekonomi; serta (iv) pekerjaan yang berkaitan dengan pengurangan atau pencegahan pembuatan segala bentuk limbah dan polusi.

1) Sebagian pekerjaan akan diganti/terganti dengan pekerjaan baru - seperti peralihan dari bahan bakar fosil menjadi bahan bakar terbarukan, atau dari produksi truk menjadi pembuatan trem (rail car), atau dari penimbunan sampah dan pembakaran limbah menjadi daur ulang.

2) Beberapa pekerjaan tertentu mungkin hilang tanpa langsung diganti karena teknologi yang digunakan sudah tidak memenuhi syarat, bahan produksi tertentu/kemasan sudah tidak boleh digunakan/dilarang di proses/pembuatannya dihentikan.

3) Banyak profesi yang ada akan ditransformasikan (seperti tukang pipa, elektrisi, tukang logam, dan pekerja konstruksi) dan ditetapkan kembali kriteria/kompetensi baru karena keterampilan yang bersangkutan atau metoda kerja sudah "dihijaukan". Dengan definisi di atas, maka proses perubahan dari pekerjaan yang ada saat ini ke pekerjaan yang ramah lingkungan/hijau dapat menghasilkan hasil positif berupa peluasan kesempatan kerja atau negatif berupa pengurangan kesempatan tergantung dari kesiapan kita untuk mempersiapkan kegiatan sektor untuk menerapkan kegiatan-kegiatan hijau.

Untuk itu, dengan berbagai perubahan kegiatan yang ada di berbagai sektor, sebetulnya telah terjadi penciptaan pekerjaan hijau. Berbagai peraturan mengenai standar lingkungan dan penerapannya di berbagai perusahaan akan mengembangkan kebutuhan perusahaan untuk lebih memperhatikan dampak dari kegiatan mereka terhadap lingkungan $(\text { Gambar } 1)^{17}$.

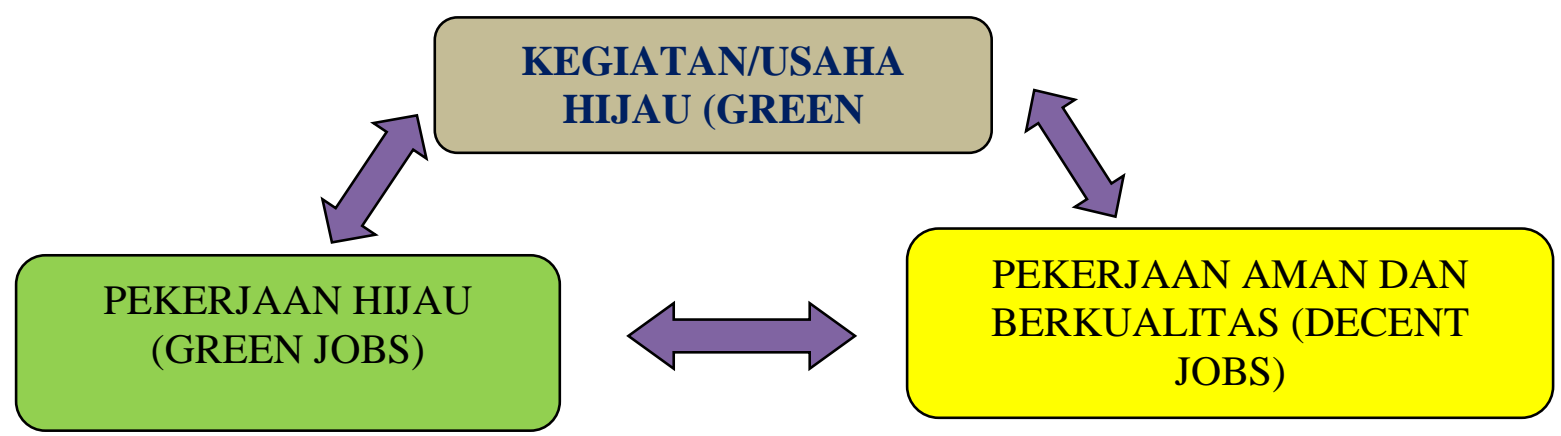

\section{Gambar 1 - Keterkaitan Green Business-green Jobs dan Decent Jobs}

Dengan demikian, perusahaan akan merekrut dan mempekerjakan pegawai dan bahkan membuat unit kerja yang menangani penggunaan bahan yang ramah lingkungan, proses produksi yang ramah lingkungan dan pengelolaan limbah agar tidak membahayakan lingkungan. Pada waktu yang bersamaan, green jobs juga dapat memberikan kualitas pekerjaan yang lebih baik kepada pekerja, karena kesadaran lingkungan akan dapat meningkatkan pula keamanan dalam pekerjaan. Meningkatnya keamanan dalam pekerjaan akan meningkatkan kualitas pekerjaan dan sehingga dapat pula menarik angkatan kerja muda untuk menggeluti pekerjaan-pekerjaan yang semula dinilai kotor, membahayakan dan tidak memberikan "prestige". Sehubungan dengan itu, penegakan peraturan lingkungan akan memiliki 3 (tiga) manfaat iaitu:

\footnotetext{
${ }^{16}$ Bappenas, 2014, Prakarsa Stategis Pengembangan Konsep Green Economy, Deputi Bidang, Sumber Daya Alam dan Lingkungan Hidup, Jakarta, hlm. 93 di akses melalui https://www.bappenas.go.id/files/6714/1170/7264/006630_buku_green_eco_ap150_2muka_17buku.pdf, pada tanggal 12 Februari 2020, pukul $14.02 \mathrm{Wib}$.

${ }^{17}$ Ibid, hlm. 94.
} 
(i) menghasilkan kualitas lingkungan yang lebih baik;

(ii) menambah lapangan pekerjaan baru yaitu pekerjaan hijau; dan

(iii) menghasilkan pekerjaan yang lebih aman dan berkualitas (decent job). Ketiga hal ini saling berkaitan dan memiliki saling ketergantungan. ${ }^{18}$

\section{Konsep Green Jobs dalam Upaya Pembangunan Hukum Ketenagakerjaan di Indonesia}

Indonesia sebagai negara yang mendasarkan pada Pancasila dan Undang-Undang Dasar Negara Republik Indonesia Tahun 1945 (UUD 1945), segala aspek kehidupan dalam bidang kemasyarakatan, kebangsaan, dan kenegaraan termasuk pemerintahan harus senantiasa berdasarkan atas hukum. Untuk mewujudkan negara hukum tersebut pada Tanggal 12 Agustus 2011 diundangkanlah Undang-Undang Nomor 12 Tahun 2011 tentang Pembentukan Peraturan Perundang-undangan (UU Nomor 12 Tahun 2011) pengganti Undang-Undang Nomor 10 Tahun 2004 tentang Pembentukan Peraturan Perundang-undangan (UU Nomor 10 Tahun 2004) yang diperlukan sebagai tatanan yang tertib di bidang pembentukan peraturan perundang-undangan. Untuk membentuk peraturan perundang-undangan yang baik, diperlukan berbagai persyaratan yang berkaitan dengan sistem, asas, tata cara penyiapan dan pembahasan, teknik, penyusunan maupun pemberlakuannya sebagaimana dijelaskan dalam Penjelasan Umum UU Nomor 12 Tahun 2011.

Dengan perkataan lain, dalam penyusunan peraturan perundang-undangan harus berdasarkan pada konsep atau norma dasar (good norms) dan sekaligus dalam rangka memberikan pengayaan dan penyamaan pemahaman tentang apa yang perlu dilakukan dan bagaimana proses dilakukan dalam penyusunan suatu peraturan perundang-undangan tersebut (good process). Pengertian peraturan perundang-undangan terdapat dalam Pasal 1 angka UU Nomor 12 Tahun 2011 yang menyatakan: "Peraturan perundang-undangan adalah peraturan tertulis yang memuat norma hukum yang mengikat secara umum dan dibentuk atau ditetapkan oleh lembaga negara atau pejabat yang berwenang melalui prosedur yang ditetapkan dalam Peraturan Perundangperundangan. Berdasarkan Ketentuan tersebut dapat diketahui bahwa unsur-unsur yang membentuk peraturan perundang-undangan yang meliputi 3 (tiga) hal, yaitu:

a. peraturan tertulis;

b. dibentuk oleh lembaga negara atau pejabat yang berwenang;

c. mengikat secara umum

Unsur pertama menyangkut bentuk produk hukum yang dikatakan sebagai peraturan perundang-undangan. Produk hukum dapat dibuat secara lisan, tetapi ada pula yang dibuat secara tertulis. Dalam kaitan dengan hal ini, semua produk hukum yang dikategorikan sebagai peraturan perundang-undangan mesti dalam bentuk tertulis. Dengan kata lain, tidak dikenal adanya produk hukum berupa peraturan perundang-undangan dalam bentuk keputusan lisan. Unsur kedua menyangkut subjek yang membentuk suatu produk hukum yang dinamakan sebagai peraturan perundang-undangan itu, mestilah lembaga negara atau pejabat yang berwenang.

Dalam kaitan dengan ini, kewenangan menjadi begitu penting, hanya lembaga negara yang diberikan kewenangan atau mempunyai kewenangan dalam pembuatan produk hukum yang dimaksud saja yang dapat membuat peraturan perundang-undangan. Dengan demikian pula apa yang dimaksud dalam Pasal 1 angka 2 UU Nomor 12 Tahun 2011 yaitu peraturan tertulis dalam bentuk statutory law atau statutory legislations, disebut pula legislative acts, yaitu kewenangan untuk mengatur atau membuat aturan (regeling) pada dasarnya merupakan domain kewenangan lembaga legislatif yang berdasarkan prinsip kedaulatan merupakan kewenangaan eksklusif para wakil rakyat yang berdaulat untuk menentukan sesuatu peraturan yang mengikat dan membatasi kebebasan setiap individu warga negara (presumption of liberty of the souvereign people).

Dalam proses pembentukan legislative acts, peranan lembaga legislatif sangat menentukan keabsahan materiel peraturan yang dimaksud. Dengan peranan lembaga legislatif yang sangat menentukan itu berarti peranan para wakil rakyat yang dipilih dan mewakili kepentingan rakyat yang berdaulat dari mana kedaulatan negara berasal sangat menentukan keabsahan dan daya ikat peraturan perundang-undangan itu untuk umum. Unsur ketiga, bahwa produk hukum itu mesti ditujukan kepada umum. Dalam hal ini bukan ditujukan kepada individu atau dalam bidang hukum sering kali digunakan istilah "bersifat mengatur". Hal ini memang tepat karena produk hukumnya saja sudah disebut sebagai peraturan perundang-undangan maka tentu juga ditujukan kepada publik, khalayak, atau kepada masyarakat, bukan kepada pribadi tertentu.

Peraturan tertulis yang bersifat umum (algemenen verbindende voorschiften) berisi norma hukum yang menurut Hans Kelsen bersifat umum dan abstrak (general and abstract norms). Norma-norma hukum yang bersifat mengatur (regeling) dengan isi norma yang bersifat umum dan abstrak (general and abstract norms) itu dituangkan dalam bentuk tertulis tertentu yang disebut sebagai peraturan perundang-undangan. Disebut peraturan (regels) karena produk hukum tersebut memang merupakan hasil atau outcome dari suatu rangkaian aktivitas pengaturan (regeling).

Menurut Abdul Manan agar hukum efektif berlaku ditengah-tengah kehidupan masyarakat, maka perubahan hukum itu harus memperhatikan tiga ketentuan yaitu; 1). Perubahan hukum itu tidak dilakukan secara parsial, melainkan perubahan itu harus menyeluruh, terutama kepada doktrin, norma-norma yang tidak sesuai dengan kondisi zaman. 2. Perubahan itu juga harus mencakupi dalam cara penerapannya. 3). Harus juga diadakan pada kaidah (aturan) yang sesuai dengan falsafah hidup bangsa Indonesia dengan harapan agar kaidah aturan yang diperbaharui itu dapat dipatuhi

\footnotetext{
${ }^{18}$ Ibid, hlm. 95.
} 
oleh masyarakat, maka dalam kaidah (aturan) itu harus memuat sanksi dan daya paksa dan untuk itu harus dibuat oleh instansi yang berwenang. ${ }^{19}$

Oleh karena itu, Pembangunan hukum ketenagakerjaan harus berlandaskan filosofis, yakni Pancasila dan landasan yuridis konstitusional, yakni Undang-Undang Dasar 1945 sebagai hukum dasar serta landasan yuridis operasional, yakni peraturan perundang-undangan yang berkaitan dengan bidang ketenagakerjaan sebagai dasar hukumnya. Di samping itu, yang tidak kalah penting adalah landasan sosiologis yakni sesuai dengan tata nilai budaya yang berlaku di masyarakat sehingga dapat menampung segala kenyataan hidup masyarakat dewasa ini. Hal tersebut dimaksudkan, bahwa pembangunan ketenagakerjaan dilaksanakan dalam rangka pembangunan manusia Indonesia seutuhnya dan pembangunan masyarakat seluruhnya. Oleh karena itu, pembangunan ketenagakerjaan dilaksanakan untuk mewujudkan manusia dan masyarakat Indonesia yang sejahtera, adil, makmur dan merata, baik materil maupun spiritual. ${ }^{20}$

Pada dasarnya masalah ketenagakerjaan merupakan agenda sosial, politik, dan ekonomi yang cukup krusial di negara-negara modern, sebab masalah ketenagakerjaan sebenarnya tidak hanya hubungan antara para tenaga kerja dengan pengusaha, tetapi secara lebih luas juga mencakup persoalan sistem ekonomi dari sebuah negara dan sekaligus sistem politiknya. Oleh karena itu, ekonomi dan politik suatu negara akan sangat menentukan corak dan warna dari suatu sistem ketenagakerjaan yang diberlakukannya. ${ }^{21}$

Selama ini persoalan ketenagakerjaan sangat ditentukan oleh sistem ekonomi dunia, sehingga mempengaruhi arah kebijakan hukum ketenagakerjaan yang melahirkan tipe hukum ketenagakerjaan seperti yang dikemukakan oleh Tamara Lothion yang membedakan tipe hukum ketenagakerjaan ke dalam tipe kontraktualis dan tipe korporatis. Tipe korporatis ini di bidang hukum ketenagakerjaan dilakukan melalui praktik kebijakan legislasi dalam bentuk pembentukan peraturan perundang-undangan sebagai usaha pemerintah untuk melakukan pembinaan hukum nasional. ${ }^{22}$

Organisasi Perburuhan Internasional (ILO) telah mencanangkan program Green jobs untuk mengurangi dampak lingkungan yang diakibatkan oleh perusahaan dan sektor ekonomi, hingga ke tingkat yang mampu melestarikan lingkungan hidup. Secara khusus, namun tidak eksklusif, hal ini mencakup pekerjaan yang dapat membantu melindungi ekosistem dan biodiversitas; mengurangi energi, materi, dan konsumsi air melalui strategi yang memiliki tingkat efisiensi tinggi; dekarbonisasi perekonomian; serta mengurangi atau mencegah pembuatan segala bentuk limbah dan polusi.

Green jobs di negara berkembang dan sedang berkembang mencakup lapangan pekerjaan bagi para manajer, ilmuwan dan teknisi dan berbagai pihak dapat memperoleh manfaat dari mereka seperti kalangan remaja, petani, penduduk desa dan penduduk perkampungan miskin. Namun ada banyak jenis pekerjaan yang pada prinsipnya hijau namun pada praktiknya tidak. Hal ini dikarenakan kerusakan lingkungan akibat terjadinya praktik-praktik yang salah. Di samping itu, bukti menunjukkan bahwa green jobs tidak secara otomatis merupakan pekerjaan layak. Banyak pekerjaan yang berhubungan dengan lingkungan merupakan pekerjaan yang "kotor, berbahaya dan sulit". Pekerjaan di sektor industri seperti daur ulang dan pengolahan limbah, energi biomass dan konstruksi cenderung bersifat berbahaya dan berupah kecil. Oleh karena itu, kebijakan tentang green jobs perlu difokuskan pada upaya untuk mengalihkan pekerjaan-pekerjaan ini menjadi pekerjaan yang hijau dan bermutu serta mampu melestarikan lingkungan hidup.

Apabila green jobs dijadikan jembatan untuk menciptakan hukum ketenagakerjaan masa depan yang benar-benar berkelanjutan, maka perubahan peraturan perundang-undangan dibidang ketenagakerjaan perlu dilakukan. Oleh karena itu. Pekerjaan yang layak dan ramah lingkungan secara efektif berhubungan dengan Tujuan Pembangunan Milenium 1 (pengurangan kemiskinan) dan Tujuan Pembangunan Milenium 7 (melindungi lingkungan hidup) yang saling melengkapi dan bukan bertentangan satu sama lain.

\section{Kesimpulan}

Segala kebijakan dan tindakan pemerintahan dan pembangunan haruslah tunduk kepada ketentuan mengenai hak asasi manusia atas lingkungan hidup yang baik dan sehat. Tidak boleh ada lagi kebijakan yang tertuang dalam bentuk undang-undang ataupun peraturan di bawah undangundang yang bertentangan dengan ketentuan konstitusional yang pro-lingkungan ini (green legislation) atau dengan perkataan lain kebijakan yang bernuansa lingkungan hidup atau hijau harus tercermin dalam setiap peraturan perundang-undangan (green legislation) sebagaimana diamanatkan dalam Pasal 44 UU Nomor 32 Tahun 2009 tentang PPLH.

Green jobs dijadikan jembatan untuk menciptakan hukum ketenagakerjaan masa depan yang benar-benar berkelanjutan, maka perubahan peraturan perundang-undangan dibidang ketenagakerjaan perlu dilakukan. Oleh karena itu, Pekerjaan yang layak dan ramah lingkungan secara efektif berhubungan dengan Tujuan Pembangunan Milenium 1 (pengurangan kemiskinan) dan Tujuan Pembangunan Milenium 7 (melindungi lingkungan hidup) yang saling melengkapi dan bukan bertentangan satu sama lain.

\footnotetext{
${ }^{19}$ Abdul Manan, 2005, Aspek-Aspek Pengubah Hukum, Kencana, Jakarta, hlm, 142

${ }^{20}$ Ujang Charda S, 2009, Mengenal Hukum Ketenagakerjaan Indonesia : Sejarah, Teori \& Praktiknya di Indonesia, Fakultas Hukum UNSUB, Subang, hlm. 25

${ }^{21}$ Abdul Jalil, 2008, Teologi Buruh, LKIS Yogyakarta, Yogyakarta, hlm. v-vi.

${ }^{22}$ Ujang Charda S, "Reorientasi Reformasi Model Hukum Ketenagakerjaan dalam Kebijakan Pemerintah", Jurnal Ilmu Hukum Syiar Hukum, Vol. XIV No. 1, Fakultas Hukum UNISBA, Bandung, Maret 2012, hlm. 9
} 
Pembangunan Hukum Ketenagakerjaan berkonsep Green Jobs, agar efektif berlaku ditengah-tengah kehidupan masyarakat, maka perubahan hukum itu harus memperhatikan tiga ketentuan yaitu; 1). Perubahan hukum itu tidak dilakukan secara parsial, melainkan perubahan itu harus menyeluruh, terutama kepada doktrin, norma-norma yang tidak sesuai dengan kondisi zaman. 2. Perubahan itu juga harus mencakupi dalam cara penerapannya. 3). Harus juga diadakan pada kaidah (aturan) yang sesuai dengan falsafah hidup bangsa Indonesia dengan harapan agar kaidah aturan yang diperbaharui itu dapat dipatuhi oleh masyarakat, maka dalam kaidah (aturan) itu harus memuat sanksi dan daya paksa dan untuk itu harus dibuat oleh instansi yang berwenang

\section{Penghargaan}

Penulis ingin mengucapkan terima kasih kepada Universiti Islam Indragiri - Tembilahan - Riau, Indonesia, atas bantuan dan maklumat yang diberikan untuk memastikan kejayaan kajian ini.

\section{Rujukan}

[1] Abdul Jalil, Teologi Buruh, LKIS Yogyakarta, Yogyakarta, 2008

[2] Abdul Manan, Aspek-Aspek Pengubah Hukum, Kencana, Jakarta, 2005

[3] Ahmad Ali, Menguak Tabir Hukum, Chandra Pratama, Jakarta. 1996

[4] Agus Dwiyanto, Reformasi Birokrasi Publik di Indonesia, Yogyakarta: Gadjah Mada University Press, 2006

[5] Arif Shidarta, Mochtar Kusumaatmadja dan Teori Hukum Pembangunan: Eksistensi dan Implikasi, Epistema Institute Huma, Jakarta. 2012

[6] Aries Harianto, Hukum Ketenagakerjaan Makna Kesusilaan dalam Perjanjian Kerja, Laksbang Pressindo, Yogyakarta, 2016

[7] Bappenas, Evaluasi Satu Tahun Pelaksanaan RPJMN 2010-2014. Jakarta: Bappenas. 2010

[8] .......... Prakarsa Stategis Pengembangan Konsep Green Economy, Deputi Bidang, Sumber Daya Alam dan Lingkungan Hidup, Jakarta. 2014

[9] Bhenyamin Hoessin, Pembagian Kewenangan Antara Pusat dan Daerah, Universitas Brawijaya Press, Malang, 2001

[10] Jawade Hafidz, “Ekologi Konstitusional (Green Constutional) Dan Kedaulatan Wilayah Di Indonesia”, Jurnal Hukum Vol XXVI, No. 2, Agustus 2011

[11] Jimly Asshiddiqie, Green Constitution: Nuasa Hijau Undang-Undang Dasar Negara Republik Indonesia Tahun 1945, PT. RajaGrafindo Persada, Jakarta, 2009

[12] Mochtar Kusumaatmadja, Konsep-Konsep Hukum dalam Pembangunan, Alumni, Bandung. 2006

[13] Romli Atmasasmita, Teori Hukum Integratif: Rekontruksi Terhadap Teori Hukum Pembangunan dan Teori Hukum Progresif. Genta Publishing, Yogyakarta. 2012

[14] Satjipto Raharjo, Ilmu Hukum, Citra Aditya Bakti, Bandung, 1991

[15] Sonny Keraf, Etika Lingkungan Hidup, Buku Kompas, Jakarta, 2010

[16] The World Bank, Country Environmental Analysis. Jakarta: The World Bank The World Bank. 2009

[17] Ujang Charda S, Mengenal Hukum Ketenagakerjaan Indonesia: Sejarah, Teori \& Praktiknya di Indonesia, Fakultas Hukum UNSUB, Subang, 2014

[18] ........... "Reorientasi Reformasi Model Hukum Ketenagakerjaan dalam Kebijakan Pemerintah”, Jurnal Ilmu Hukum Syiar Hukum, Vol. XIV No. 1, Fakultas Hukum UNISBA, Bandung, Maret 2012 